\title{
Research on the Attitude towards Islam of Medieval European -Take Historian William of Malmesbury as Case
}

\author{
Yifan Sun ${ }^{1}$ \\ ${ }^{1}$ Sichuan University, Chengdu, Sichuan, China, 610064 \\ hunter2011@foxmail.com
}

Keywords: Mamo William Salisbury; Islam; East

\begin{abstract}
In early medieval, Europeans generally distinct Islam from Christian as a pagan. 12th century, exchanges of Europe and the Arab world in the military and cultural gradually increased, so that the Islam stereotype of scholars changed gradually. During this period of England's famous historian William Salisbury Mamo under the influence of the Renaissance secular trend and was attracted by the crusades and the grand theme of East-West conflict, he made a certain amount of research and it had achieved relative more rational understanding.
\end{abstract}

\section{Introduction}

In medieval Europe, people generally know very little about Islam. Most Europeans early twelfth century Islamic civilization still think this is described in "Song of Roland" in that Saracens are polytheists, idolaters, and Muhammad is their worship The gods in one. This Saen is called "ignorance of the times" in 1120 changed later by Pope initiated the Crusades campaign so that each Christian ethnic groups live in Western Europe had the opportunity to close contact with the Muslim East, Spain and AC Sicilian Region and Eastern European scholars among scholars is gradually increasing, the West against the Islamic civilization traditional stereotype therefore been changed. Europeans transition concept in Muslim East, the twelfth-century England, William of Malmesbury Historians Mamo is worthy of study is an important figure. The historian's life has never been away from England, but it is the first European scholars of Islam and Muhammad described a rational person. This article will be about the Islamic culture narratives William preliminary study, expected to be able to take to enhance the understanding of medieval East-West traffic history.

\section{People Began to Focus on Islam}

Europeans traditionally considered Islam Saracens and other pagan peoples no difference. In the "Song of Roland" in Welch, Slavs, Ava two, Bulgarians, Hungarians and Saracens enjoyed gentiles common feature - do not believe in God and worship idols. In the eyes of Christians, idolatry is always associated with immorality. "Old Testament" in the Ten Commandments to Moses on Mount Sinai recipient, decadent Jews at the foot of the Taurus to establish the worship of idols were the result angered God. Similarly, only the worship of Muhammad, Tway Ghent, affecting the sub wheel of such idols Saracens in mind Europeans are also negative. Them in order to win the war against Charlemagne, willing his eldest son as a sacrifice, offered to idols; they have no sense of purpose to provoke a war, beheaded opponents sent envoys in the war on the battlefield the escape, even after the failure of his idol before the crack.

As Mamo William Salisbury monk scholars have various types of transactions are extremely strong thirst for knowledge, which enabled him to invest in the East closed the monastery in the twelfth century environment in attention, with a more rational eyes look at Islamic culture in Christian terms this relatively heterogeneous culture. In the "History of the Kings of Britain" in William said: "Saracens and Turks to worship the Creator God, the Prophet Muhammad regarded their message was not God, but in the fate of Westerners worship, their. Idol arranged in every important place. San Jeronimo in his discussion of Isaiah eighteen works also proved to us that the Egyptians and almost all other Asian peoples are doing. "During this narrative we can see that 
William has abandoned the "song of Roland" in Islam and Saracens Europeans stereotype, to separate the Saracens having polytheism and idolatry practices of various ethnic East region Come.

William was the first to the Middle Ages the West Slavs idolatry, pagan superstitions and Islamic monotheistic thought to distinguish and emphasize Islam, the prophet Muhammad as a man rather than God. He not only correctly recognized that the nature of the non-Islamic idolatry, but also on the link between religion and Christianity this has a certain understanding. William said: "Although Christians and Jews and Saracens Son differences on the issue, but they have faith in the hearts of God, admitted that he was the creator of all things." By these words we can know, William considered Judaism the difference between Christianity and Islam are not monotheistic and polytheistic or difference between Christianity and paganism, but the difference with the different factions within a system.

\section{East-West Cultural Complexity}

Despite the growing number of East and West makes William Islamic culture has relatively rational understanding, but for the Eastern religions and Christianity homologous William's attitude is more complex. On the one hand, after identifying the origins of Islam, as a scholar William Europeans abandoned the long-standing stereotype pagan Saracens. However sympathetic understanding of the concrete may be able to eliminate stereotypes, but the presence of the West since ancient times "Oriental impression" cannot do anything. Ancient Greece Aristophanes drama began, "Oriental" in the eyes of Westerners on the autocratic, feminine and even evil these negative, negative traits tied stakeholders. Roman historian Lucan "within Wars," a book once thought the world the more the more moderate temperatures to the East, "a warm climate makes the character becomes weak." So not good Oriental Parthian campaign, lack of bloody, will only be used in long-range combat drug bow. Lucan such human mental state and ethnic character and geography and climate of a region linked to the practice is more common in the classical world of ethnographic interpretation. On the classical learning William has a deep knowledge of the inheritance of this "West - East" imagination. In his "History of the Kings of England" in William by Pope Urban's speech to express his "West-East" these two cultures view. He described the Franks and the Turks like Bi Lukan book, like the Romans and Parthians. Franks heroic, sacrifice because they were born in colder regions; and the Turks Born in the East, long withstand high temperature exposure, become very timid. They "never dared close combat, but only hid the distant arrows in the back."

In William's life, Europeans combined with their history of Eastern and Western prejudices Islamic forces come to this conflict combine the notion that Islam has greed for territory, they occupied the whole delusional world, and in the pace will not stop until they reach this goal. There are even rumors that the Christian God to punish impious, specially sent 20 Saracens depart by boat from Spain landed in the territory of Christianity, the Christians slaughtered, the generation of today's Lagarde Frey Carolina region into Muslim territory.

Medieval Europe about the Muslim concept of aggressive affects the William views on the nation. In the "History of the Kings of England" in William quoted Charlemagne Alcuin about war letters to fight the infidels. The letter praised the Charlemagne Alcuin first generals to the Spanish coastal areas from the hands of the Saracens behavior, but then he lamented, saying that most of these "cursed Saracens, they will throughout the Arab and Asian non-American area are included in the bag!. "For William, the huge population and rich history of aggressive behavior Muslim people is undoubtedly quite disturbing factor.

From the big era background, in addition to the impact on the political, military, and exchanges between the 12th century in Western Europe and Eastern Islamic release more in culture, especially in the field of scientific knowledge. Saved the Arabs down the ancient Greek natural philosophy, scientific work during this period has been a large number of Italian cities scholars translated into Latin, introduced to Europe, and ultimately led to the revival of the High Middle Ages in Europe of scientific theory. Through the efforts of Robert Heller Crawford British scholars such knowledge Arab astronomy, calendar terms were introduced to England, William and thus have access to Arab science and culture. In the "History of the Kings of England" in William described Gebert emphasis 
on astronomy, arithmetic and other Arab scientific achievements, but also mentioned that the Arab astronomy books. This suggests that time William and cultural knowledge Arabia also has considerable knowledge of science.

Considering the above facts, presumably William the Islamic religious culture has a rational understanding, while regular contact with Arab scholars of scientific knowledge in his writings spend a large amount of space must not only describe the Islamic civilization attitudes reflect a bias . I believe that William attention to Islamic civilization, the difference in his historical narrative embodied between East and West, all the historians of the more ambitious a topic-conflict with the Islamic Arab concerns expression. In the history of Western historiography, the first concern is the subject of Herodotus' History of the Persian War. " In this book, the conflict surrounding the Greek as the representative of the West and the East to Persia, represented between the father of Western history, with delicate brush strokes depict in detail the culture, customs and history of each nation East. Such attention to the war in human history, political changes and other great theme is the basic feature of ancient Greek, Roman historiography. However, since the beginning of Eusebius, Ecclesiastical History of Western style represents the emergence of a shift in the history of writing, Christian historians no longer concerned about changes in the secular history of the world, instead of the eyes are focused on the church history of changes.

The 12th century, with Latin classical literature began to appear in the revival of the tendency of secularization, Christian historian of European works. Through the eyes of some Christian historians Gothic church stained glass, colorful falls in the real world. On the Latin classical literature has a deep knowledge of William obviously affected this unit intellectually wave of secularization. So, when dealing with Islamic issues, William little mention of faith on the conflict between the two, but more practical level to consider it from colliding with Christianity. He thinks before being expelled from Rome's Urban reason to mobilize the whole of Europe Asian expedition, first, to help master the army to seize power, the second is to realize its ambitions in Macedonia and other regions. William really care about is the Oriental Islamic civilization to Western Christian living space a real threat in the land, on the advantages of the population, as well as the expanding nation. In his view, Islam and Christianity are homologous religion, the conflict between them is not on ideology, the West really wants to guard against the population and territory of the Islamic expanding. So, although the war mobilization Urban reason not noble, William still think of the Crusades as a defensive war, to ensure Western security is very necessary.

\section{Conclusion}

In the early middle ages, Europeans impression of Islam and Muslims mainly reflected in the "Song of Roland" in the description of the Saracens. In White Wolf Kangding, Marcy was represented by pagan king Jianhua, cunning, do not keep vows, it is synonymous of evil. Over time, alternating between Europe and the Orient gradually increased so that this stereotype of Christian scholars get changed. Mamo Salisbury William as England's most knowledgeable historians Renaissance twelfth century, Islam has a more profound understanding. On the one hand, he clearly recognized the pagan Islam is not in the traditional sense, but with the Jewish, Christian monotheism homologous, while well-known preacher Muhammad entrepreneurial story. On the other hand, under the influence of the European tradition of Eastern and Western ideas, William of Expansion of oriental Islamic civilization was very nervous that the Muslim expansion in the East of the world will squeeze the living space of Christians in Europe.

\section{References}

[1] J.A.Giles.tr William of Malmesbury, Chronicles of Kings of England,London:Bohn,1847,p208

[2] R. W. Southern, Western Views of Islam in the Middle Ages ,Massachusetts: Harvard University Press, 1962 pp34-45.

[3] R.M. Thompson, William of Malmesbury, Woodbridge: The Boydell Press ,2003,p169 
[4] Susanna Morton Braund trs, Lucan: Civil War, Oxford University Press,1992,pp162-163

[5] William of Malmesbury, Chronicles of Kings of England,P361

[6] I.B. Tauris, The church in the early middle ages: The I.B. Tauris History of the Christian Church ,I.B.Tauris\&Co.Ltd,2005,P31

[7] I.B.Tauris, The church in the early middle ages: The I.B. Tauris History of the Christian Church ,p31

[8] William of Malmesbury, Chronicles of Kings of England,P84

[9] William of Malmesbury, Chronicles of Kings of England, P173

[10] Arnaldo Momigliano, "Tradition and the classical historian "History and Theory, 1972, Vol3, p284.

[11] R.M. Thompson, William of Malmesbury, pp183-184. 